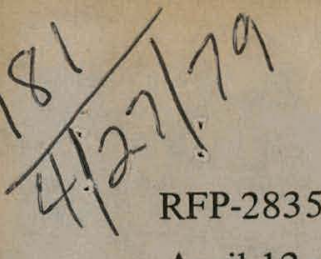

April 12, 1979
RFP-2835

April 12, 1979

\title{
RECOVERY OF PLUTONIUM FROM INSULATION, SCRAP GLASS, \\ AND SAND-SLAG RESIDUES
}

Donald L. Ziegler

John E. Garnett

Chemistry R\&D

PILOT PLANT DEVELOPMENT

John K. Fraser

Analytical Laboratories

CHEMICAL OPERATIONS SUPPORT LABORATORY

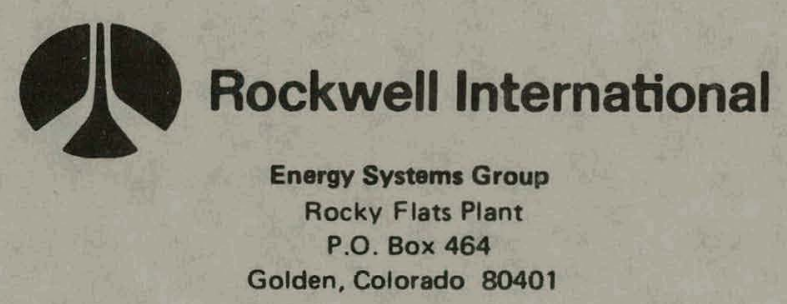

U. S. DEPARTMENT OF ENERGY

CONTRACT DE-AC04-76DPO3533 


\section{DISCLAIMER}

This report was prepared as an account of work sponsored by an agency of the United States Government. Neither the United States Government nor any agency Thereof, nor any of their employees, makes any warranty, express or implied, or assumes any legal liability or responsibility for the accuracy, completeness, or usefulness of any information, apparatus, product, or process disclosed, or represents that its use would not infringe privately owned rights. Reference herein to any specific commercial product, process, or service by trade name, trademark, manufacturer, or otherwise does not necessarily constitute or imply its endorsement, recommendation, or favoring by the United States Government or any agency thereof. The views and opinions of authors expressed herein do not necessarily state or reflect those of the United States Government or any agency thereof. 


\section{DISCLAIMER}

Portions of this document may be illegible in electronic image products. Images are produced from the best available original document. 


\section{LEGAL NOTICE}

This report was prepared as an account of work sponsored by the United States Government. Neither the United States nor the Department of Energy, nor any of their employees, nor any of their contractors, subcontractors, or their employees, makes any warranty, expressed or implied, or assumes any legal liability or responsibility for the accuracy, completenesss or usefulness of any information, apparatus, product or process disclosed, or represents that its use would not infringe privately owned rights.

Printed in the United States of America

Available from the

National Technical Information Service

U. S. Department of Commerce

Springfield, Virginia 22161

Price: Printed Copy $\$ 4.50$ Microfiche $\$ 3.00$

Price Is Subject to Change Without Notice 


\section{RECOVERY OF PLUTONIUM FROM INSULATION, SCRAP GLASS, AND SAND-SLAG RESIDUES}

Donald L. Ziegler

John E. Garnett

Chemistry R\&D

PILOT PLANT DEVELOPMENT

John K. Fraser

Analytical Labnratories CHEMICAL OPERATIONS SUPPORT LABORATORY

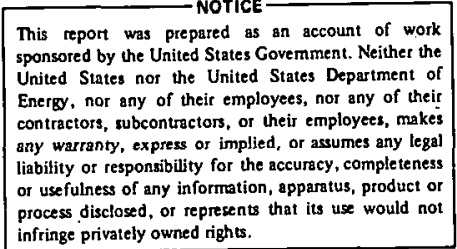

ROCKWELL INTERNATIONAL

ENERGY SYSTEMS GROUP ROCKY FLATS PLANT

P.O. BOX 464

GOLDEN, COLORADO 80401
SUBJECT DESCRIPTORS

Glass

Leaching

Plutonium Recovery

Plutonium Residues

Discard Limits

Waste Processing

Fluxing

Slag

Prepared under Contract DE-AC04-76DPO3533

for the

Albuquerque Operations Office

U.S. Department of Energy 
RFP-2835 


\section{CONTENTS}

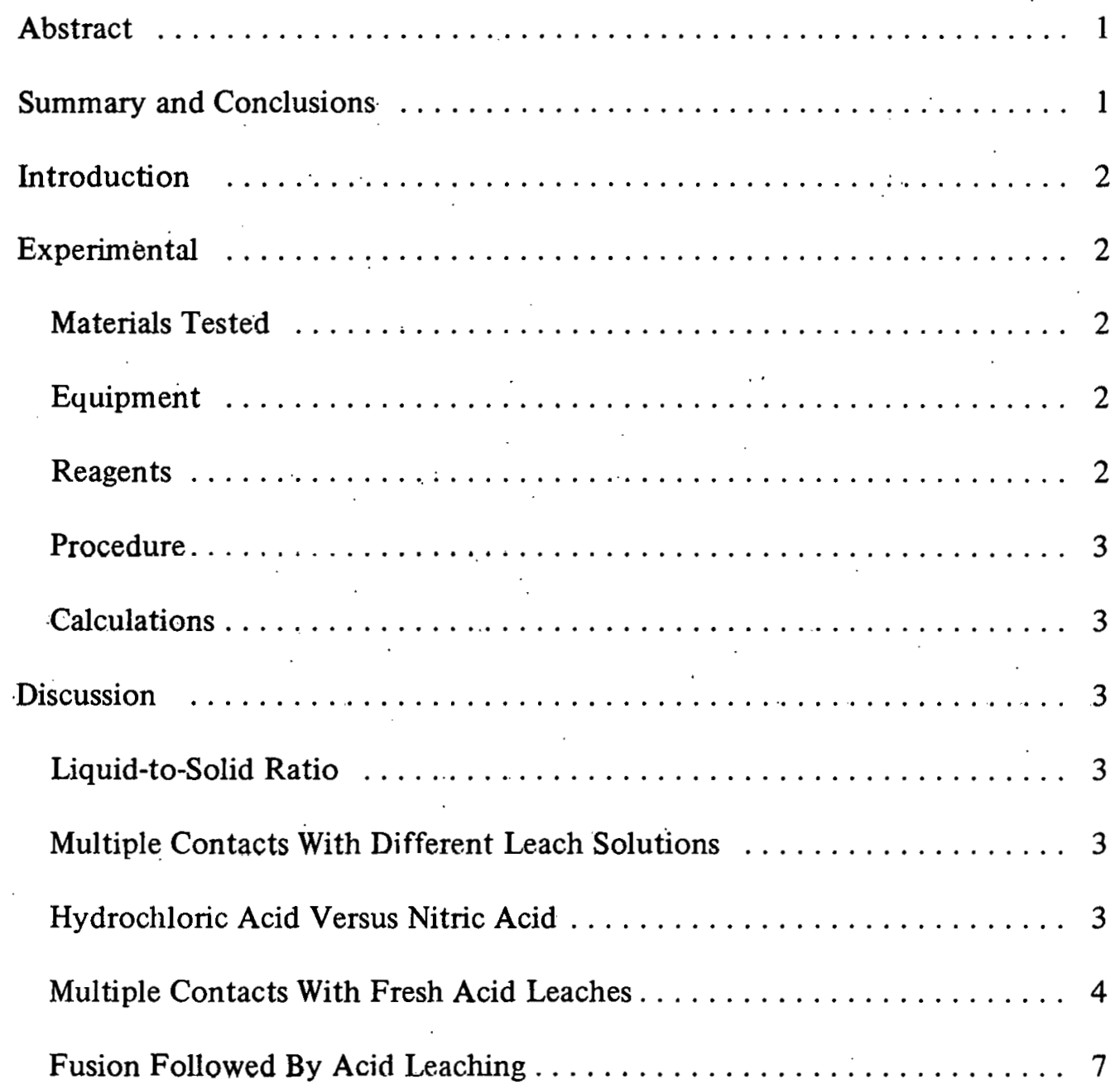


RFP-2835 


\title{
RECOVERY OF PLUTONIUM FROM INSULATION, SCRAP GLASS, AND SAND-SLAG RESIDUES
}

\author{
Donald L. Ziegler, John E. Garnett, and John K. Fraser
}

\begin{abstract}
Laboratory experiments were performed to evaluate methods for removing plutonium from insulation, glass leach heel, and sand and slag heel. The methods evaluated included hydrochloric acid leaching, nitric acid leaching, and a treatment consisting of a fusion step followed by acid leaching. Results indicate that a nitric'acid leach is effective in lowering the plutonium concentration of these solid wastes to the desired limit, if multiple contacts are used. A hydrochloric acid leach was found to be superior to a nitric acid leach for removing plutonium from the residues.
\end{abstract}

\section{SUMMARY AND CONCLUSIONS}

Experiments were performed to find an effective method of recovering plutonium from insulation, glass leach heel, and sand and slag heel. Heel is the undissolved solids remaining after the nitric acid-calcium fluoride leaching of the residue in the plutonium recovery process at the Rocky Flats Plant. The objective was to evaluate methods of plutonium recovery that would produce a waste containing less than $7 \times 10^{-4}$ gram of plutonium per gram of solid. This amount is one-tenth the value of the economic discard limit used at the Plant when this study was initiated. Hydrochloric acid leaching, nitric acid leaching, and a fusion step followed by acid leaching were the methods examined.

The following variables were considered: liquid-to solid ratio (milliliters of liquid per gram of solid), multiple contacts with fresh leach solution, fusion media composition, and successive contacts with different leach solutions.
This study indicates that hydrochloric acid leaching and fusion followed by leaching will recover plutonium, but these techniques could present problems if implemented. Hydrochloric acid leaching would cause corrosion of process equipment, and it is incompatible with the rest of the nitric acid-based recovery systems. Fusion of waste materials requires high temperatures and increases the volume of waste material.

Contacting the residues with successive batches of fresh nitric acid is effective, but at least four contacts are necessary, and each leach is an expensive process. More experiments are needed, and more samples of Plant waste must be collected to determine the optimum method of recovering plutonium from these materials. Conclusions from this report are summarized as follows:

1. Four contacts with fresh nitric acid resulted in a plutonium concentration below the desired goal for all three materials tested.

2. A contact with nitric acid followed by leaching the heel with hydrochloric acid reduced the plutonium concentration to $6 \times 10^{-4}$ grams of plutonium per gram of solid for the insulation; however, this technique was ineffective for sand and slag heel.

3. Fusion followed by a leach with hydrochloric acid removed up to $70 \%$ ( $~ 0.002$ gram of plutonium per gram of residue) of the plutonium from sand and slag heel, depending on the fusion media.

4. The liquid-to-solid ratio is significant in leaching, and it improved plutonium recovery about $12 \%$ when increased from $2: 1$ to $5: 1$. 
5. The type of acid used for leaching was found to be a factor, with hydrochloric acid leaches being consistently more effective than nitric acid leaches.

\section{INTRODUCTION}

Production operations at Rocky Flats produce wastes that are treated in the plutonium recovery area. Contaminated residues are generated not only in the recovery area, but also in the ion exchange system where the plutonium is purified. These residues are subjected to a bulk assay to determine which residues contain sufficient plutonium to warrant recovery.

Because of the desirability of reducing both the quantity and the radionuclide concentration of the solid waste, this study was made to determine if more plutonium could be recovered from insulation, glass leach heel, and sand and slag heel. Americium recovery was also studied, but not as extensively because of its lower concentration (three orders of magnitude).

Experiments were performed using hydrochloric acid leaching, nitric acid leaching, and fusion followed by acid leaching to dissolve plutonium out of the materials tested. If hydrochloric acid is used as a leach, the plutonium must be precipitated and returned to the nitric acid system for purification. Methods of returning the plutonium to the nitric acid system have been discussed elsewhere.*

\section{EXPERIMENTAL}

\section{Materials Tested}

1. Insulation - Material had not been leached in the production recovery process. The plutonium concentration was $1.15 \times 10^{-2}$ gram of plutonium per gram of material.

2. Glass Leach Heel - Ground-glass frit that had been leached in the production recovery process; it

${ }^{*}$ D. L. Ziegler, J. W. Lindsay, and J.K. Fraser. Evaluation of Methods to Recover Plutonium From Incinerator Ash. RFP-1723. Dow Chemical U.S.A., Rocky Flats Plant, Golden, Colorado. August 16, 1971 contained $8 \times 10^{-3}$ gram of plutonium of material.

3. Sand and Slag Heel - Material had been leached in the production recovery process, but still contained $1.05 \times 10^{-2}$ gram of plutonium per gram of material.

\section{Equipment}

A 1000-ml boiling flask was used for leaching all but the fused samples; they were leached in a $250-\mathrm{ml}$ flask. The flasks were fitted with glass condensers to reflux the vapor. Heating and stirring were accomplished by a combination hot plate-stir plate using a Teflon-coated stir bar.

Leached material was filtered through a mediumporosity glass filter attached to a suction flask: Fusion took place in a ceramic crucible heated in a muffle furnace.

\section{Reagents}

The hydrochloric acid leach solution contained $10 \mathrm{M}$ hydrochloric acid, $1.0 \mathrm{M}$ tin chloride, and $0.1 \mathrm{M}$ hydrofluoric acid. The nitric acid leach solution was varied according to the test. For the successive contact of nitric acid, then hydrochloric acid, the nitric acid leach sulution contained $12.5 \mathrm{M}$ nitric acid and $0.4 M$ calcium fluoride. This same composition was used for the multiple contact test with the glass heel.

The insulation was contacted five times with $10 M$ nitric acid and $0.4 M$ calcium fluoride. The sand and slag heel was contacted five times with $12.5 \mathrm{M}$ nitric acid and $0.84 M$ aluminum nitrate.

Fusion media compositions were varied for each of the seven runs. The different media, as shown in the following list, were combined with $3 \mathrm{~g}$ of sand and slag heel for each run. 
Fusion Media

\begin{tabular}{|c|c|}
\hline Run & (g) \\
\hline i & $3-\mathrm{NaOH}, 3-\mathrm{AlCl}_{3}$ \\
\hline 2 & $3-\mathrm{NaCl}, 3-\mathrm{AlCl}_{3}$ \\
\hline 3 & $6-\mathrm{AlCl}_{3}$ \\
\hline 4 & $6-\mathrm{NaOH}$ \\
\hline 5 & 3-NaOH, 3-Evap. Sal \\
\hline 6 & 6-Evap. Salts \\
\hline 7 & 3-Evap. Salts, 3-AlCl \\
\hline
\end{tabular}

\section{Procedure}

The material to be leached was weighed to $0.1 \mathrm{~g}$ and placed in a boiling flask. A leaching solution of known volume and composition was added to the flask. The resulting mixture was then stirred and heated to boiling. After a predetermined length of time, the solution was cooled and filtered; the residual solid was then washed with diluted acid. Both the dried solid and the filtrate were sampled and assayed for plutonium.

Fusion was accomplished by weighing the test material into a crucible, adding a known fusion media, mixing, and heating to a known temperature. After cooling, the fusion product was broken up . and leached as in the other experiments.

\section{Calculations}

$\% \mathrm{Pu}$ recovered $=$

$$
(\mathrm{Pu} \text { in solution } \mathrm{wt}) \times 100
$$

$(\mathrm{Pu}$ in solution $\mathrm{wt})+(\mathrm{Pu}$ in residue $\mathrm{wt})$

$\%$ solid dissolved $=\frac{(\text { wt of feed }- \text { wt of residue }) \times 100}{\text { wt of feed }}$

\section{DISCUUSSION}

\section{Liquid-to-Solid Ratio}

The effect of varying the liquid-to-solid ratio (milliliter of solution per gram of solid material) on removing plutonium from test material was examined with a hydrochloric acid leach solution.
Results of this experiment are shown in Table 1. Liquid-to-solid ratios of $2: 1$ and $5: 1$ were both successful in dissolving most of the plutonium from the insulation and the glass leach heel. The 5:1 leach ratio, however, increased plutonium recovery from 86 to $97 \%$ for the insulation, and from 73 to $85.5 \%$ for the glass leach heel. Americium recovery from insulation was over $90 \%$ for both leach ratios, but increased from 60 to $96 \%$ when the higher ratio was used on glass leach heel: Solids dissolution was independent of the liquid-to-solid ratio.

\section{Multiple Contacts With Different Leach Solutions}

An experiment using a nitric acid leach followed by a hydrochloric acid leach, each for a two-hour contact time, was performed on sand and slag heel, and on insulation. The data are presented in Table 1. The first leach of sand and slag heel recovered $25 \%$ of the plutonium, but the second leach was only $5 \%$ efficient for an accumulative recovery of $29 \%$. These two leaches still removed less plutonium than the $32 \%$ that one hydrochloric acid leach removed.

The first leach of insulation dissolved 93\% of the plutonium and the second leach dissolved $70 \%$ of the remaining plutonium for an accumulative recovery of $98 \%$. This was $12 \%$ better than one hydrochloric acid leach at a liquid-to-solid ratio of $2: 1$, but only $1 \%$ better than one at a 5:1 liquid-to-solid ratio. The recovery of americium paralleled the behavior of the plutonium, with the percent dissolved being slightly less for insulation, and slightly greater for sand and slag heel.

\section{Ḧydrochloric Acid Versus Nitric Acid}

The preceeding two experiments provide the data to compare the acid leach solutions used. At the same liquid-to-solid ratio, the hydrochloric acid solution dissolved more plutonium and americium than the nitric acid solution. The percent of plutonium dissolved from the insulation increased from 93 to $97 \%$ with the hydrochloric acid, and the percent of americium dissolved increased from 91 to $95.5 \%$. Solids dissolved also increased from 51 to $58 \%$ with the hydrochloric acid system. 
TABLE 1. Amount of Material Recovered by Acid Leaches

\begin{tabular}{|c|c|c|c|c|c|c|c|}
\hline \multirow[b]{2}{*}{ Waste } & \multirow[b]{2}{*}{ Run } & \multirow[b]{2}{*}{ Leach Solution* } & \multirow[b]{2}{*}{$\begin{array}{l}\text { Liquid-to-Solid Ratio } \\
\text { (ml liquid/g solid) }\end{array}$} & \multicolumn{3}{|c|}{ Material Dissolved } & \multirow{2}{*}{$\begin{array}{l}\text { Plutonium Concentration } \\
\text { in Heel } \\
\text { (g Pu/g solid) }\end{array}$} \\
\hline & & & & $\begin{array}{l}\text { Plutonium } \\
\text { (\%) }\end{array}$ & $\begin{array}{c}\text { Americium } \\
(\%)\end{array}$ & $\begin{array}{l}\text { Solids } \\
(\%)\end{array}$ & \\
\hline \multirow[t]{4}{*}{ Insulation } & 1 & $\mathrm{HCL}$ & $2: 1$ & 86 & 94 & 57 & $3.7 \times 10^{-3}$ \\
\hline & 2 & $\mathrm{HCL}$ & $5: 1$ & 97 & 95.5 & 58 & $0.8 \times 10^{-3}$ \\
\hline & 3 & $\mathrm{HNO}_{3}$ & $5: 1$ & 93 & 91 & 51 & $1.6 \times 10^{-3}$ \\
\hline & $4 * *$ & $\mathrm{HCL}$ & $2: 1$ & 98 & 96.5 & 60 & $0.6 \times 10^{-3}$ \\
\hline \multirow[t]{2}{*}{ Glass Leach Heel } & 1 & $\mathrm{HCL}$ & $2: 1$ & 73 & 60 & - & $2.2 \times 10^{-3}$ \\
\hline & 2 & $\mathrm{HCL}$ & $5: 1$ & 85.5 & 96 & - & $1.2 \times 10^{-3}$ \\
\hline \multirow[t]{4}{*}{$\begin{array}{l}\text { Sand and Slag } \\
\text { Leach Heel }\end{array}$} & 1 & $\mathrm{HCL}$ & $2: 1$ & 32 & 28 & 22 & $9.2 \times 10^{-3}$ \\
\hline & 2 & HCL & $5: 1$ & - & - & 23 & \\
\hline & 3 & $\mathrm{HNO}_{3}$ & $5: 1$ & 25 & 36 & 2 & $8.0 \times 10^{-3}$ \\
\hline & $4 * *$ & $\mathrm{HCL}$ & $2: 1$ & 29 & 38 & 12 & $8.5 \times 10^{-9}$ \\
\hline
\end{tabular}

*HCL solution $=10.0 M \mathrm{HCL}, 1.0 \mathrm{M} \mathrm{SnCl}$, and $0.1 M \cdot \mathrm{HF}$ $\mathrm{HNO}_{3}$ solution $=12.5 \mathrm{MHNO}_{3}$ and $0.4 M \mathrm{CaF}_{2}$

**Run 4 is a leach of Run 3; the percent dissolved is an accumulative percent.

Both nitric and hydrochloric acid were ineffective with the sand and slag heel, removing only 25 and $32 \%$ of the plutonium, respectively. Weight reduction of the sand and slag heel was $2 \%$ with nitric acid and $23 \%$ with hydrochloric acid. More plutonium, americium, and solids were removed by hydrochloric acid leaches than nitric acid leaches, but there are drawbacks to the hydrochloric acid. To recover plutonium from the hydrochloric acid solution, the plutonium must be precipitated and redissolved in nitric acid so as to be compatible with the existing purification process at Rocky Flats. Hydrochloric acid also causes corrosion problems in the present production system.

\section{Multiple Contacts With Fresh Acid Leaches}

The effect of multiple contacts with fresh leach solution was studied for the three test materials. Insulation was contacted five times with a nitric acid leach, as shown in Figure 1. The contacts were for two hours with each contact involving a liquid- to-solid ratio of $5: 1$. The initial contact removed $87 \%$ of the plutonium, with the later contacts being less cfficient; only 10 to $20 \%$ of the remaining plutonium were removed per contact. After a total of four contacts, $94 \%$ of the plutonium had been removed, and the plutonium concentration in the residues was $4 \times 10^{-4}$ grams of plutonium per gram of solid. Solid dissolution dropped from $60 \%$ on the first contact to less than $5 \%$ on the next four contacts.

Glass leach heel was also contacted five times with nitric acid. The data from this experiment are presented in Figure 2. Each contact in this series was for two hours with a liquid-to-solid ratio of $5: 1$. The first leach solution contact removed $77 \%$ of the plutonium; subsequent contacts dissolved only between 13 and $34 \%$ of the remaining plutonium per contact. Four contacts resulted in $91 \%$ of the initial plutonium being dissolved, thus reducing the residue concentration to $7 \times 10^{-4}$ grams of plutonium per gram of solid. Again, the removal of solids was less than $5 \%$ after an initial $25 \%$ solid dissolution. 


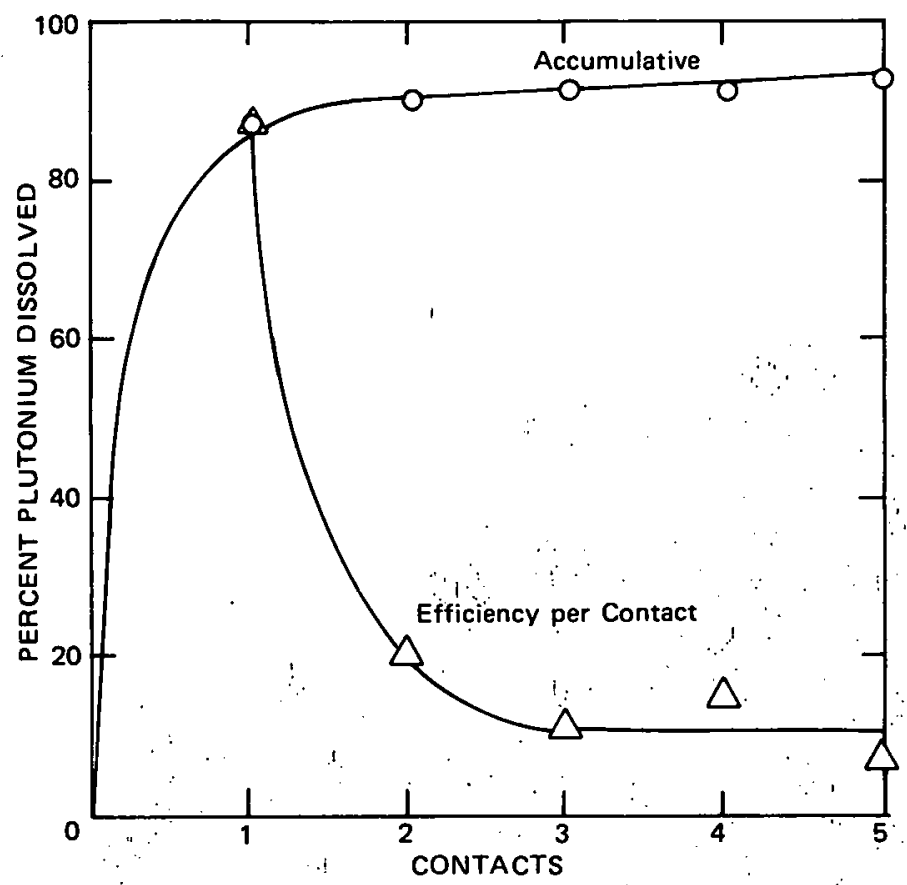

FIGURE 1. Multiple Contacts Study Using Insulation $5: 1$ liquid-to-solid ratio
2-livur contacts
$12.5 M \mathrm{HNO}_{3}$ and $0.4 M \mathrm{CaF}_{2}$ leach solution
25 gof insulation initially

FIGURE 2. Multiple Contact Study Using Glass Leach Heel

Legend
2:1 liquid-to-solid ratio
$12.5 M \mathrm{HNO}_{3}$ and $4 M \mathrm{CaF}_{2}$ leach solution
$50 \mathrm{~g}$ of glass initially

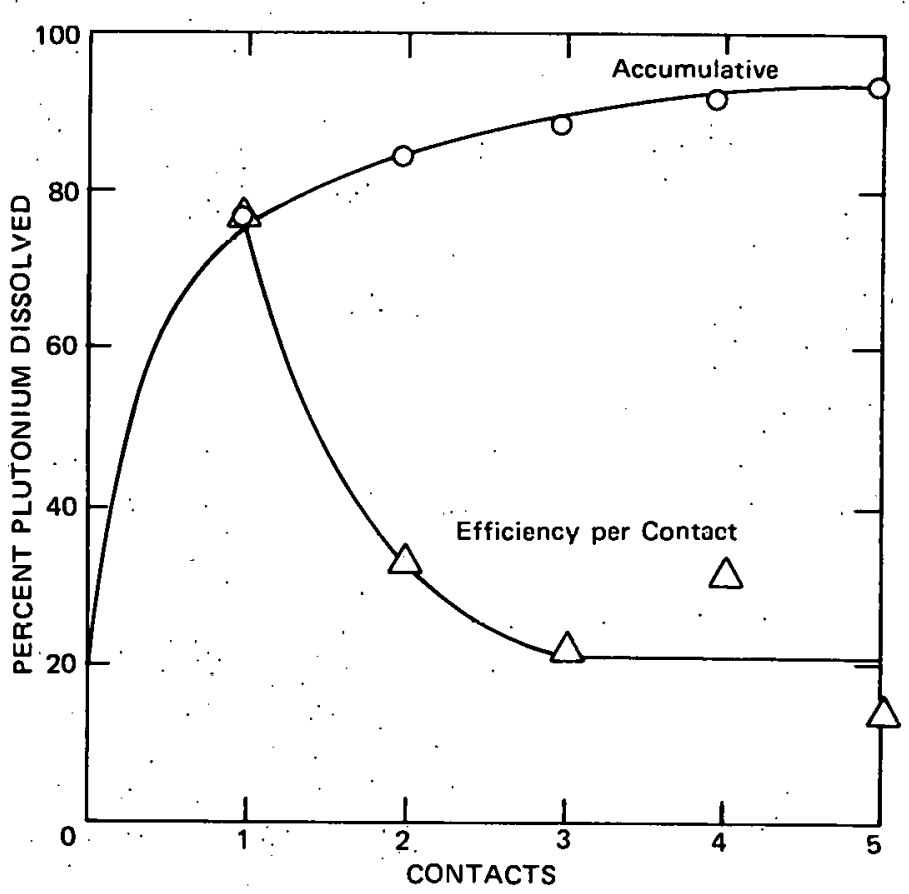


RFP-2835
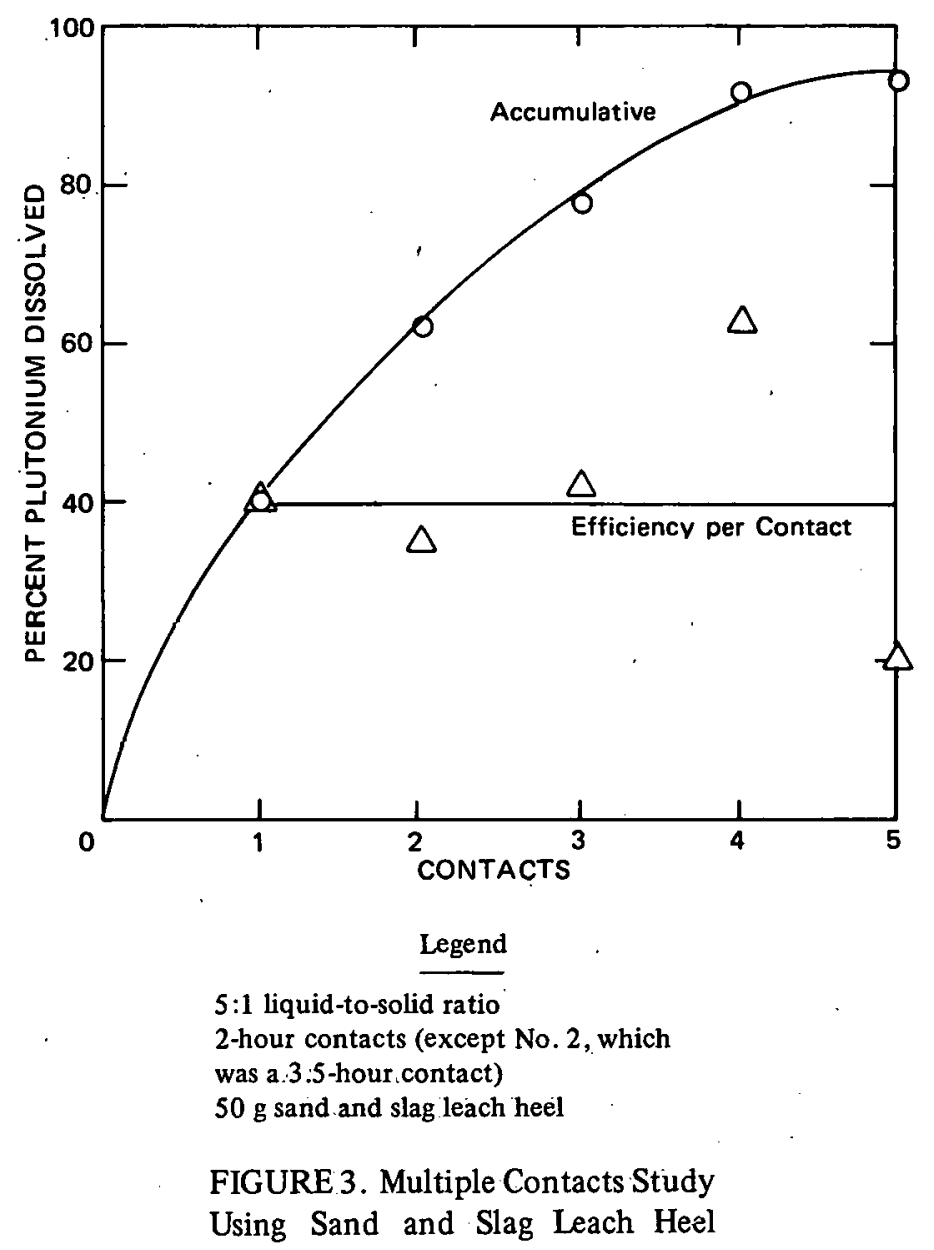

TABLE 2. Results of Fusion. Tests With Sand and Slag Heel

\begin{tabular}{|c|c|c|c|c|c|c|}
\hline Run & $\begin{array}{c}\text { Fusion Media Weight } \\
\text { (g) }\end{array}$ & $\begin{array}{l}\text { Heel Weight } \\
\text { (g) }\end{array}$ & $\begin{array}{l}\text { Fusion Temp } \\
\left({ }^{\circ} \mathrm{C}\right)\end{array}$ & $\begin{array}{l}\text { Leach Solution } \\
\text { (ml) }\end{array}$ & Leach Solution & $\begin{array}{l}\text { Plutonium Recovered } \\
\text { (\%) }\end{array}$ \\
\hline 1 & $\begin{array}{l}\text { 3-NaOII } \\
\text { 3-AlCI, }\end{array}$ & 3 & 450 & 30 & $\begin{array}{l}10 M \mathrm{HCl} \\
2 M \mathrm{AlCl}_{3}\end{array}$ & 55.24 \\
\hline 2 & $\begin{array}{l}3-\mathrm{AlCl}_{3} \\
3-\mathrm{NaCl}\end{array}$ & 3 & 850 & 30 & $\begin{array}{r}10 M \mathrm{HCL} \\
2 M \mathrm{AlCl}_{3}\end{array}$ & 70.16 \\
\hline 3 & $6-\mathrm{AlCl}_{3}$ & 3 & 850 & 30 & $\begin{array}{r}10 M \mathrm{HCL} \\
2 M \mathrm{AlCl}_{3}\end{array}$ & 38.73 \\
\hline 4 & $6-\mathrm{NaOH}$ & 3 & 450 & 30 & $\begin{array}{l}10 M \mathrm{HCL} \\
2 M \mathrm{AlCl}_{3}\end{array}$ & 45.71 \\
\hline 5 & $\begin{array}{l}\text { 3- } \mathrm{NaOH} \\
\text { 3-Fvap Salts }\end{array}$ & 3 & 450 & 30 & $\begin{array}{l}10 M \mathrm{HCL} \\
2 M \mathrm{AlCl}_{3}\end{array}$ & 48.25 \\
\hline 6 & 6-Evap Salts & 3 & 450 & 30 & $\begin{array}{r}10 M \mathrm{HCL} \\
2 M \mathrm{AlCl}_{3}\end{array}$ & 49.85 \\
\hline 7 & $\begin{array}{l}\text { 3-Evap Salts } \\
\text { 3-AlCl }\end{array}$ & 3 & 450 & 30 & $10 M \mathrm{HCL}^{*}$ & 66.35 \\
\hline
\end{tabular}


The results of five contacts between sand and slag heel and nitric acid are shown in Figure 3. Contact time varied from 2 to 3.5 hours with a liquid-tosolid ratio of 5:1. The plutonium dissolved in the first contact was only $40 \%$, but successive contacts removed from 20 to $65 \%$ of the remaining plutonium per contact. The difference in efficiency of removal of plutonium in the contacts is not due to the variation in contact time." This observation is based on the second lowest efficiency corresponding to the one period of extended contact time, contact number two. When graphed (Figure 3 ), the series of contact efficiencies indicate a steady recovery rate of about $40 \%$ for each leach. The fourth contact resulted in an accumulative $61 \%$ plutonium recovery. It is speculated that the analytical results were in error and that the calculated recovery should have been lower. This speculation may be supported by the fact that the $40 \%$ efficiency for the last two contacts would have resulted in the same final residue concentration. The solid dissolution follows a similar trend, averaging $13 \%$ per leach, rather than declining in later contacts. The total amount of plutonium dissolved was $92 \%$ after four contacts. This resulted in a residue concentration of $6 \times 10^{-4}$ grams of plutonium per gram of solid. In each series of multiple contacts, the plutonium concentration of the material tested was reduced to the desired limit. Americium recovery efficiencies were similiar to those of plutonium, but the concentrations were three orders of magnitude less.

\section{Fusion Followed By Acid Leaching}

Methods of fusing sand and slag heel, then leaching the fusion product, were examined in an attempt to dissolve more of the plutonium than was dissolved by a simple leaching. Table 2 shows the conditions of the fusion, the leaching, and the results of the process. The seven trials removed from 39 to $70 \%$ of the plutonium from the heel. This is a greater quantity than was removed by simple leaching, but less than was removed in the multiple contact experiment.

The most successful fusion media was one that contained equal parts of $\mathrm{AlCl}_{3}$ and $\mathrm{NaCl}$ by weight. Problems associated with the fusion process were the necessity of high temperatures $\left(450\right.$ and $850^{\circ} \mathrm{C}$ ) and the increased waste due to addition of the fusion media. To reduce the amount of salt in the fusion process, waste generated in the aqueous waste treatment operation at Rocky Flats was tested as a substitute for fresh fusion salts. The results, using evaporator salts, were not encouraging, however, when compared to multiple-contact acid-leach experiments. 
RFP-2835 